JOM, Vol. 66, No. 11, 2014

DOI: $10.1007 / \mathrm{s} 11837-014-1167-9$

(C) 2014 The Minerals, Metals \& Materials Society

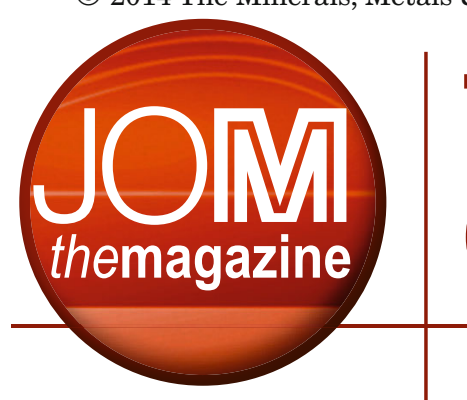

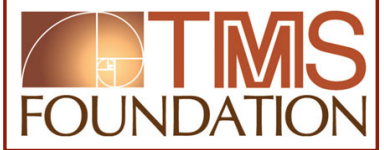

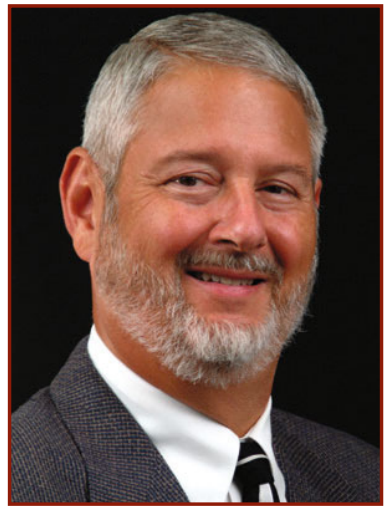

Robert H. Wagoner TMS Foundation Board of Trustees Chair

\title{
TMS Foundation: growth through giving
}

\section{A New Beginning for the TMS Foundation}

\section{By Robert H. Wagoner}

I have heard many stories since the TMS Foundation revitalization began two years ago. Although my principal focus has been on raising funds, few of these stories have been about money.

\section{Here is what these stories are about:}

They are about students who gained the confidence they needed to complete their degree programs and embark on their careers. ("An award like this tells you, 'Yes, you can do this, you can do it well, and you deserve to be here, '”: Nicholas De Leon, 2008 J. Keith Brimacombe Presidential Scholarship Recipient.)

They are about our young colleagues in the earliest, most vulnerable stages of their professional careers who were given opportunities to connect with mentors. ("As a new faculty member, this award makes it possible for me to continue attending the TMS annual meeting even though I don't yet have funded research to pay for conference travel. I am very grateful to the TMS Foundation for making it possible for me to remain connected to the society and my research community during this period of my career.": Amber Genau, 2014 Young Leader Professional Development Award Winner.)

They are about how emerging leaders are developing fruitful working relationships across the globe. ("This was a tremendously rewarding experience that the TMS 2014 Annual

Meeting and Exhibition.) resulted in my making critical connections and developing new friendships that will last my entire career.": Michele V. Manuel, 2014 TMS/Japan Institute of Metals and Materials Young Leader International Scholar.)

Each and every story is about ensuring the relevance and impact of our profession in the future.

The TMS Foundation does not simply hand out checks. We provide a calling card that helps our award and scholarship recipients open doors and a stepping stone from which they can launch and grow their careers.

\section{Here is what these stories do not reveal:}

The Foundation has been working quietly, behind the scenes, since 1993, and supporting deserving programs such as those cited above - albeit at a rate much greater than our endowment can sustain over the past several years. Without your help, these programs could be scaled back or eliminated. Even worse to contemplate is the possibility of the Foundation's slowly going out of existence.

This unpleasant reality dictates the Foundation Board of Trustees (and my!) principal goal: $100 \%$ participation of the TMS membership, with significant help from every volunteer and every member who can afford it. Our aspirations as a Foundation are great, so our need for your support is equally great.

The Board of Trustees understands that the TMS Foundation has not done enough to convey such stories as I related above in the past, nor has it made clear its precarious financial position. We are working hard to make up for those failings. Starting in December, we will be launching the first TMS Foundation Annual Appeal.

Last year at this time, the Board of 
Trustees was able to raise more than $\$ 120,000$ in donations and new pledges simply by asking past donors to help revitalize the Foundation. (This represented a more than $700 \%$ increase from overall giving levels of past years! This amount meant that the Foundation did not need to spend the endowment principal, but the structural deficit remains as stated.)

Our first annual appeal helps open the conversation on what the Foundation has been able to accomplish and what is needed to sustain it. It will also allow each of you to participate meaningfully in success stories such as those presented at the beginning of this article.

\section{Here are examples of recent initiatives that you can help support in the long-term:}

- Tripling the number of Young Leader Professional Development Awards

- Adding an Early Career Faculty Fellow Award

- Increasing the number of seats in the Emerging Leaders Alliance

- Creating the inaugural Ellen Swallow Richards Diversity Award

Big or small, pledge or donation, we need your generosity to continue the great

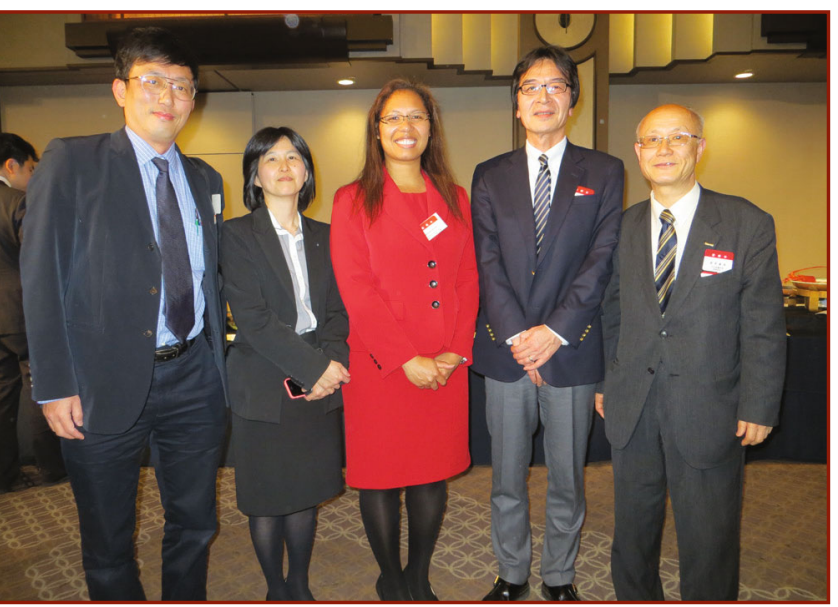

Michele Manuel (center, in red), 2014 TMS/Japan Institute of Metals and Materials (JIM) International Scholar, experienced a productive week at the JIM 2014 Annual Spring Meeting in Tokyo, Japan, through the support of the TMS Foundation.

things that the Foundation is doing, as well as to develop new initiatives. Our goal is to increase the TMS Foundation endowment from its present level of $\$ 2$ million to $\$ 4.5$ million within five years. We have set a very high bar, but cannot achieve that without a groundswell of support from TMS members.

So, when you receive your TMS Foundation 2014 Annual Appeal information, please open your hearts and checkbooks. Make a difference to our profession and its young members. This is your opportunity to "pay it forward" in a professional context.

I look forward to adding your story as a contributor to the TMS Foundation 2014 Annual Appeal.

\section{Support the 2014 Annual Appeal}

The TMS Foundation 2014 Annual Appeal will run through December 31, 2014. TMS members will be receiving information in early December, with the option to mail a check as a contribution or to conveniently and securely make a donation online at the TMS Foundation website at www .TMSFoundation.org/contribute. Donations can also be processed over the phone by contacting Mary Samsa, TMS Foundation \& Public Affairs Manager, at (724) 814-3130 or msamsa@tms.org.

\section{Last Chance to Be a Founding Member}

With the close of the 2014 Annual Appeal on December 31, so closes the opportunity to be a founding member of one of the TMS Foundation's new honorific societies. The Foundation established these new recognition levels to honor those who have made generous donations over the course of a lifetime. They are:

- Diamond Society $(\$ 100,000$ or more)

- Gold Society $(\$ 20,000$ or more)

- Silver Society (\$5,000 or more)

New founding members will be honored at the TMS Donor Recognition Event now being planned for the TMS 2015 Annual Meeting \& Exhibition (TMS2015) in Orlando, Florida, March 15-19. To learn more, contact Mary Samsa at (724) 814-3130 or msamsa@tms.org.

TMS Foundation Board of Trustees

Robert H. Wagoner

Board of Trustees Chair

Professor Emeritus,

The Ohio State University

Hani Henein

2014 TMS President

Foundation Trustee

Professor,

University of Alberta

Patrice Turchi

TMS Vice President

Foundation Trustee

Advanced Metallurgical

Science and Engineering

Group Leader,

Lawrence Livermore

National Laboratory

Elizabeth A. Holm

TMS Past President

Foundation Trustee

Professor,

Carnegie Mellon University

Robert W. Hyers

TMS Financial Planning Officer

Foundation Trustee

Chief Technology Officer,

Boston Electrometallurgical

Corporation

Diran Apelian

Foundation Trustee

Alcoa-Howmet Professor of Mechanical Engineering,

Worcester Polytechnic Institute

Stanley M. Howard

Foundation Trustee

Professor, South Dakota

School of Mines \&

Technology

Alexander Scott

Foundation Trustee

Emeritus TMS Executive

Director

Garry W. Warren

Foundation Trustee

Professor Emeritus,

University of Alabama

James J. Robinson

Foundation Secretary TMS Executive Director 